\title{
A SPATIO-EMOTIONAL ANALYSIS OF THE DISGUST DISCOURSE IN CONTEMPORARY AFRODIASPORIC FICTION: ADICHIE'S AMERICANAH AND BULAWAYO'S WE NEED NEW NAMES
}

\author{
UN ANÁLISIS ESPACIO-EMOCIONAL \\ DEL DISCURSO DEL ASCO EN LA FICCIÓN \\ AFRODIASPÓRICA CONTEMPORÁNEA: \\ AMERICANAH, DE ADICHIE Y WE NEED NEW \\ NAMES, DE BULAWAYO
}

\author{
ÁNGELA SUÁREZ RODRÍGUEZ \\ Universidad de Oviedo \\ suarezangela@uniovi.es
}

\begin{abstract}
The purpose of this paper is to provide a critical comparative analysis of the disgust discourse in Chimamanda Ngozi Adichie's Americanah (2013) and NoViolet Bulawayo's We Need New Names (2013) so as to better understand the current politics of Afrodiasporic subjectivation. Built primarily on Sara Ahmed's reflections on the emotional economies of disgust developed in The Cultural Politics of Emotion (2004), the discussion explores the relationship between space, emotions and subjectivity from the perspective of the "emotional turn" which is still under development within Postcolonial and Gender Urban Studies. This approach has enabled the understanding of the geographies of disgust in the two selected novels as an illustration of the exclusion process of racialisation in present urban spaces. Moreover, the interpretation of their protagonists as personifications of Isabel Carrera Suárez's "post-colonial and post-diasporic pedestrian" (2015) has showed how an abject condition in non-western cities is primarily the result of the diverse forms of violence resulting from a failed process of decolonisation, while this corresponds to an ambivalent social positionality in the hegemonic metropolis. Social abjection has been thus revealed as a fundamental negotiation status in the subjectivation process of contemporary Afrodiasporians.
\end{abstract}

Keywords: geographies of disgust, abject condition, Afrodiasporic subjectivity, Chimamanda Ngozi Adichie, NoViolet Bulawayo. 


\section{Ángela Suárez Rodríguez}

\section{Resumen}

El propósito de este artículo es aportar un análisis crítico comparativo del discurso del asco en Americanah (2013), de Chimamanda Ngozi Adichie, y We Need New Names (2013), de NoViolet Bulawayo, para obtener un conocimiento más profundo de las políticas actuales de subjetivación afrodiaspórica. La discusión, fundamentada principalmente en las reflexiones de Sara Ahmed en The Cultural Politics of Emotion sobre las economías afectivas del asco (2004), examina la relación entre el espacio, las emociones y la subjetividad desde la perspectiva del "giro emocional" que todavía está desarrollándose dentro de los Estudios Urbanos Postcoloniales y de Género. Este planteamiento ha permitido reconocer las geografías del asco en las dos novelas seleccionadas que ilustran los procesos de racialización de los espacios urbanos contemporáneos. Asimismo, la identificación de sus protagonistas como personificaciones del "peatón" postcolonial y postdiaspórico de Isabel Carrera Suárez (2015) ha revelado que la condición abyecta en las ciudades no occidentales resulta principalmente de las diversas formas de violencia que se derivan de un proceso de descolonización fallido, mientras que este se corresponde con una posicionalidad social ambivalente en la metrópolis hegemónica. En este sentido, la abyección social se revela como una forma de negociación fundamental en el proceso de subjetivación de los sujetos afrodiaspóricos contemporáneos.

Palabras clave: geografías del asco, condición abyecta, subjetividad afrodiaspórica, Chimamanda Ngozi Adichie, NoViolet Bulawayo.

\section{Introduction}

The main purpose of this paper is to provide a critical comparative analysis of the disgust discourse in Chimamanda Ngozi Adichie's Americanah (2013) and NoViolet Bulawayo's We Need New Names (2013) so as to better understand the process of formation and reconfiguration of current Afrodiasporic subjectivities. Notwithstanding their almost opposite representations of an Afrodiasporic experience of displacement, both novels have been acclaimed as outstanding representatives of contemporary Afrodiasporic literature written in English. The winner of both the National Book Critics Circle Award for Fiction and The Chicago Tribune Heartland Prize for Fiction in the same year of its publication, Adichie's Americanah was in addition shortlisted for the Baileys Women's Book Prize for Fiction in 2014 and the International IMPAC Dublin Award in 2015. It tells the story of Ifemelu, a middle-class teenager from Nigeria who moves to the United States in search of a better education and becomes a popular "race 
blogger". We Need New Names, which won the 2014 PEN/Hemingway Award for Debut Fiction, has led Bulawayo to become the first black African woman and Zimbabwean to be shortlisted for the Man Booker Prize. In contrast to Ifemelu, its protagonist is a ten-year-old girl called Darling, who migrates to the United States to escape her poverty-stricken life in Zimbabwe and faces her adolescence as an illegal immigrant.

This article draws from the idea that the study of the urban spaces depicted in contemporary postcolonial literatures provides a comprehensive basis for understanding the power dynamics which shape present social relations, notably through a consideration of their emotional dimension. The discussion must then be read from the perspective of the "emotional turn" which is still under development within Postcolonial and Gender Urban Studies. Based on these premises, an examination of the relationship between space, emotions and subjectivity within the urban context will constitute the theoretical basis for an analysis of the disgust discourse in the two selected novels. In particular, Sara Ahmed's reflections on the emotional economies of disgust developed in The Cultural Politics of Emotion (2004) will be fundamental for the interpretation of the disgust-invoking images in both Adichie's Americanah and Bulawayo's We Need New Names. This approach will enable the identification of the spatioemotional textualities representing geographies of disgust as an illustration of the exclusion process of racialisation in present urban spaces. In turn, this will lead to an understanding of their protagonists as personifications of Isabel Carrera Suárez's "postcolonial, post-diasporic pedestrian" (2015: 854), mainly on account of their rendering as sentient subjects of the abjectionality which they both inhabit and embody. Ultimately, this will drive the discussion to evaluate the impact of a social condition of abjection on the subjectivation process of contemporary Afrodiasporians.

\section{Space, Emotions and Subjectivity in the Postcolonial City}

In their introduction to The New Blackwell Companion to the City, Gary Bridge and Sophie Watson paraphrase Joyce Davidson, Mick Smith, Liz Bondi and Elspeth Probyn when they observe that, "while emotions have always been profoundly present in academic studies", in fact, "it is only relatively recently that their import has been widely, or at least openly, felt and discussed as a topic in its own right" (2011: 278). The inauguration in 2008 of the journal coedited by these four scholars, Emotion, Space and Society, has been one of the most substantial indications of the new academic interest in emotions within disciplines 


\section{Ángela Suárez Rodríguez}

such as Urban Studies (Bridge and Watson 2011: 278). Nevertheless, as Sara Ahmed argues in a reference to Anu Koivunen, it is important to acknowledge the longer history of this focus within Gender Studies because of the traditional "conceptual links between woman, body and emotion" (Ahmed 2014: 205). In particular, Guénola Capron has explained that feminist and queer contributions were crucial for the emergence of the so-called "emotional turn" in the Social Sciences due to their questioning of both androcentrism and the patterns of male domination (2014: 161), insisting on the political implications of the personal.

In "Intensities of Feeling: Towards a Spatial Politics of Affect", Nigel Thrift notes that, "given the utter ubiquity of affect as a vital element of cities", logic would suggest "that the affective register" has constituted a large part of the examination of urban spaces (2004: 57). However, as the geographer points out, "[ $\mathrm{t}]$ hough affect continually figures in many accounts", the reality is that it has been "usually off to the side" in urban studies. It is for this reason that, as he remarks, "to read about affect in cities", it has been usually necessary to resort to the literature of modernist writers as celebrated as Virginia Woolf or James Joyce (2004: 57), for the academic focus on the urban emotional experience in the work of Georg Simmel, Jane Jacobs, Walter Benjamin or Richard Sennet has been an exception to the general rule (Bridge and Watson 2011: 279). Having said this, it is important to note that Simmel was for a long time one of the few scholars to develop an interest in "the emotional dimension of the built environment" (Lupton 1998: 153). Moreover, he was a precursor of the postmodern emphasis on the individual's multiple experiential "narratives", which laid the basis for the shift in perspective within Urban Studies from attention to the economic to a focus on the cultural and the aesthetic dimension of the urban (Lindón 2007: 7). It was in particular the new interest in intangible realities, such as experience and perception (Menéndez Tarrazo 2010: 44), which stressed the importance of considering the urban space from the perspective of the sentient subject (Lindón 2007: 11), thus fostering the turn to emotion in Urban Studies.

Both Simmel and Benjamin's focus on the connection of the physical context of the city, the sensory and imaginative responses to this space, as well as the formation of subjectivities, was later a matter Michel de Certeau resumed through his emphasis on the daily practice of walking in the city (Menéndez Tarrazo 2010: 45). His contribution to Urban Studies is based on the idea of "spatial stories" because, as Alicia Menéndez Tarrazo argues, the imaginative appropriation of the urban space occurs through their creation and is thus paramount for the construction of subjectivity (2010: 46). However, despite the 
resistant nature of de Certeau's walker to the "boundaries of an imposed spatial grammar", Isabel Carrera Suárez has noted that one of the main weaknesses of this figure is its disembodied character (2015: 856). Inspired by Marsha Meskimmon's aesthetic pedestrianism, she argues that, in contrast to flânerie, pedestrianism involves "physical and emotional engagement with" the urban space which is "shared and inhabited" (857). The most substantial difference from de Certeau's figure is, hence, that "the postcolonial and post-diasporic pedestrian" provides a better representation of "the racialized, gendered and sexualized subjects" in current postcolonial cities (Carrera 2015: 856). Moreover, as in the case of Chimamanda Ngozi Adichie and NoViolet Bulawayo, among other contemporary Afrodiasporic authors, Carrera Suárez adds that her pedestrian is representative of "the street walkers created (and sometimes embodied) by black and immigrant writers in the United States, whose observing and traversing of cities is conducted from the perspectives of alterity" (2015: $855)$.

The explicit postcolonial approach of Carrera Suárez's proposal points to the importance of reflecting on the essential contribution of postcolonialism to the interpretation of cities, principally its calling into question the Eurocentric focus of traditional urban studies (Menéndez Tarrazo 2010: 103). As Lindón observes, the cultural expressiveness of cities is diverse, but hegemonic urban imaginaries only recognise the cultural expressions of certain social sectors with linkages to power, while the rest of urban cultural images are invisibilised or ignored (2007: 13). It is precisely for this reason that Menéndez Tarrazo notes that modern cities constitute to some extent a landscape where the logic of colonialism still prevails (2010: 111). For her part, Ahmed has also reflected upon the postcolonial status of modern cities through her conception of the figure of the stranger as "the cultural other", in the sense that she sees this individual as constituted through power relations that are embedded in the past as much as in the present (2000: 8). According to her, "colonialism is structural rather than incidental to any understanding of the constitution of both modernity and postmodernity" (10), and therefore "the encounters between embodied others" can only be understood through post-coloniality (14). Indeed, Kirsten Simonsen has noted that " $[\mathrm{p}]$ ostcolonial thinking has gained relevance to analyses of the internal conditions in Western cities because of the circumstances under which immigration and settlement of the immigrants have occurred" in these spaces. In particular, Simonsen believes that the failure of hegemonic cities to deal with these everyday strange encounters "has imported (post)colonialism into the cities and produced spatially segregated and racialized geographies" (2008: 147), notably through institutional practices and discourses with a significant emotional burden. 


\section{Emotional Economies of Disgust and the Abject Condition}

Sara Ahmed's seminal theory in The Cultural Politics of Emotion draws on the premise that, although usually related to "the presumption of interiority" (Ahmed 2014: 8), "emotions should not be regarded as psychological states, but as social and cultural practices" (2014: 9). For her, as Deborah Lupton had claimed in The Emotional Self: A Sociocultural Exploration (1998), emotions need to be understood as resulting from cultural definitions and social interactions with others. In this sense, Ahmed presents an approach to emotions "as a form of cultural politics or world-making" which aligns some bodies with others and, at the same time, marginalises other bodies within communities (2014: 12). More specifically, she bases the principle of her model of "affective economies" on the idea that emotions do not "inhabit anybody or anything" (2014: 46; emphasis in original), but as "effects of circulation" (2014: 8), they move and "stick" to "create the very surfaces and boundaries that allow all kinds of objects to be delineated" (2014: 10).

In a similar vein, Ben Anderson has more recently observed that emotions "attach to places and bodies and so condition without determining how those places and bodies are and can be related to" (2017: 28). He stresses, moreover, that emotions "are unevenly distributed and imbricated in processes of distribution" which "enact, express and reproduce [...] patterns of urban inequalities" (26). In the case of disgust, Ahmed understands that the relation of this emotion to power becomes clear when we consider both the spatialising procedure of its related repulsive reactions "and their role in the hierarchising of spaces as well as bodies" (2014: 88). Because "it involves a relationship of touch and proximity between the surfaces of bodies and" those entities which are perceived as a threat, she sees disgust as fundamentally "dependent upon contact" (2014: 85). To be more precise, Ahmed explains that the spatialisation implied in its functioning is based on an avoidance of contact as a response to the identification of an actual or potential threat of contamination (2014: 85). Therefore, following its perception as "the key to an understanding of exclusion" (Sibley 1995: 11), Ahmed has identified disgust as crucial in the establishment of social segmentation (2014: 88).

Drawing from Julia Kristeva's reflections in her Powers of Horror: An Essay on Abjection, where the author describes the abject as that which is "opposed to $I$ " (1982: 1; emphasis in original), Ahmed stresses that it is the examination of the relationship between disgust and the alienating condition of abjection that enables the comprehension of the reason why "some forms of contact are felt to 
be disgusting (and not others)" (2014: 86). As noted by Ellen Hostetter through a reference to Ian Burkitt, "[e]ach emotion is "expressive of patterns of relations", and "disgust $[\ldots]$ is an emotion that expresses a particular set of unequal power relations" (2010: 285). Hostetter explains that disgust "leads to a social and spatial hierarchy with those in power defined as pure" opposing "a defiled other, rejected, and excluded by wider society" (285). In this regard, Ahmed has argued that the perception of these "others" as disgusting is the result of an emotional stickiness which "depends on histories of contact that have already impressed upon the surface of the object" (2014: 90) - this being the reason why black bodies are "already seen as dirt, as the carrier of dirt" (82). Indeed, it is along these lines that, as Hostetter has proposed, disgust cannot only be seen as "giv[ing] meaning and force to a racial ideology" (2010:289), but as fragmenting the landscape along racial lines (283). Disgust, as a spatialising emotion, creates boundaries and establishes a distance from the racialised "other" through a process of social abjectification in contemporary urban spaces.

Imogen Tyler has described social abjection as an exclusionary social force of sovereign power which "strip[s] people of their human dignity and reproduce[s] them as dehumanized waste, the disposable dregs and refuse of social life" (2013: $21)$. She sees this condition as a prism through which to examine current "states of exclusion from multiple perspectives" (4), and especially from the view of those perceived by Anne McClintock as "obliged to inhabit the impossible edges of modernity" (in Tyler 2013: 4). Ahmed's observation that one of the most important features of disgust is its ambivalent nature provides a valuable insight into this positionality Tyler relates to the paradoxical need for the "surplus" that immigrants represent (2013: 20). For her, in line with Ahmed's consideration that disgust involves "desire for, or an attraction towards, the very objects that are felt to be repellent" (2014: 84), this has to do with the desire "to both constitute the boundaries of the state and $[\ldots]$ legitimate the prevailing order of power" (Tyler 2013: 20). In other words, despite important objections to immigration, undocumented migrants are a fundamental tool in the current capitalist global structure, mainly because of the cheapness that their absence "of welfare benefits" implies, but "also because of their vulnerability to deportation and their lack of legal rights" (Hayter 2004: 157). This "inclusive exclusive" logic Tyler has identified thus demonstrates that these socio-spatial processes are not opposite mechanisms in the present neoimperialist world (2013: 20). Furthermore, it seems to be a crucial factor in the renegotiation of the abjectionality which conditions the subjectivation process of contemporary postcolonial migrants. 


\section{Decoding the Depiction of Disgust and the Abject in Adichie's Americanah and Bulawayo's We Need New Names}

Ifemelu, the protagonist of Chimamanda Ngozi Adichie's Americanah, is a middle-class teenager from Lagos who moves to the United States in her college years in search of a better education. The novel recounts her romance with Obinze, who decides to settle in Britain, from the beginning of their relationship in secondary school to their reunion back in Nigeria. After more than a decade living in diaspora, Ifemelu decides to return to Nigeria in spite of her success as a popular "race blogger" in the United States. Indeed, the narration opens with Ifemelu on her way to a salon to have her hair braided as part of her preparation for her return to Lagos. The importance of considering the depiction of what could be read as her displacement from the centre to the urban peripheries of the hegemonic metropolis lies in its possible interpretation as an illustration of the racial fragmentation of this urban space. The initial lines of the novel, which refer to some of her similar experiences in the past, demonstrate this possibility:

During her first year in America, when she took New Jersey Transit to Penn Station and then the subway to visit Aunty Uju in Flatlands, [Ifemelu] was struck by how mostly slim white people got off at the stops in Manhattan and, as the train went further into Brooklyn, the people left were mostly black and fat. (Adichie 2014: 5)

This description of the spatialisation of race in New York City is then emphasised through the clarification that her memories correlate with her experiences at present. Ifemelu reveals that "[i]t still startle[s] her $[\ldots]$ what a difference a few minutes of train travel ma[kes]" when she later in this initial chapter reflects on her journey from Princeton to Trenton to have her hair braided (2014: 5). In the same vein, the narration provides details that contrast Princeton Junction Station in New Jersey, where all the people on the platform are "white and lean" (4), and the platform in Trenton, the southernmost stop in the state, which "was crowded with black people, many of them fat, in short, flimsy clothes" (5). Besides a clear contrast between racially marked urban fragments, Ali Madanipour's fundamental consideration that the "socio-spatial phenomenon" of exclusion is "multidimensional" becomes, thus, evident through the representation of a socioeconomic gap (2016: 206), which is especially noticeable in the description of the population's physical construction and way of dressing.

The delimitation of racially marked geographies within the western metropolis becomes even more apparent when the narrator provides details about the neighborhood Ifemelu enters in her search for the braiding salon in Trenton. The image of chaos and dirtiness is explicitly associated with the black population in the 
area when the narrator clarifies that this is "the part of the city that had graffiti, dank buildings and no white people" (Adichie 2014: 9). Then the narration narrows even more its spatial focus and describes, in the same vein, the moment Ifemelu enters the salon from which the whole story is articulated through the use of flashbacks. This is situated in "a shabby block", which is limited to a room depicted as "thick with disregard, the paint peeling" (9), and which, after a while, begins "to nauseate her, with its stuffy air and rotting ceiling" (363). In addition to recognising Ifemelu as a sentient subject of the place because of her spaceinduced nausea, it is worth noticing that this feeling of sickness has been traditionally identified as one of the main results of experiencing revulsion (Rozin and Fallon in Ahmed 2014: 84). Ifemelu's perception of this crucial space in the narrative in terms of disgust is indeed stressed when she wonders why the braiders could not "keep their salon clean and ventilated" (Adichie 2014: 363).

The connection between a disgust discourse and the depiction of the alienation of the racialised "other" in the hegemonic metropolis in Americanab is also noticeable when the narrator provides further details on the place where Ifemelu lives upon her arrival in the United States. This is the apartment of her Aunt Uju in Flatlands, who had left Nigeria some years earlier to finish her medical training. The narration highlights Ifemelu's surprise when she realises that "[a] fat cockroach was perched on the wall near the cabinets, moving slightly up and down as though breathing heavily" (Adichie 2014: 106). In Lagos, "she would have found a broom and killed it", but in this black dominant part of Brooklyn "she left the American cockroach alone and went and stood by the living room window" (106). While the presence of this insect, usually seen as a "carrier of dirt" (Ahmed 2014: 54), reveals the abject character of the space inhabited, Ifemelu's distancing from the insect this time could be read as the result of the fear of contamination which characterises a feeling of disgust (Adichie 2014: 83) — that is, as an effort to avoid becoming a despised subject “through 'taking on' the qualities already attached to the roach" (54). Nevertheless, it is important to realise that her abject condition appears to be already determined by her spatial segregation in the alleged land of opportunity.

Just as Adichie's narrative opens with a spatial opposition in the setting of the racially fragmented western metropolis, so NoViolet Bulawayo's We Need New Names also begins with a revealing spatial contrast. This differs, however, from the depiction in Americanah in that its characters appear to move on this occasion from the margins to the centre of the non-western urban space. Darling, the protagonist, is ten and lives in a poverty-stricken shantytown called Paradise because her house has been demolished. Here she spends her days playing games with her friends and stealing guavas until she moves to the United States to live with her Aunt Fostalina, where she deals with the challenges of being an 


\section{Ángela Suárez Rodríguez}

undocumented immigrant. The narration opens with the depiction of the children in the middle of their routine trip from Paradise to a place described "not like Paradise" but "like being in a different country altogether" (Bulawayo 2013: 4). This is named Budapest, a location that mostly consists of white people with a higher social status, so that Darling sees it as "a nice country where people who are not like [them] live" (4).

A better visualization of this spatial depiction can be had by following through the correlation between the fictional spatial opposition between Paradise and Budapest and the conception of the Manichean colonial city Frantz Fanon presented in The Wretched of the Earth (1961). In her contribution to The Cambridge Companion to the City in Literature, Caroline Herbert argues that, in Fanon's view, the colonial city consisted of two distinct parts which represent "the spatial practices of the imperial imaginary" (2014: 201). Budapest would correspond with Fanon's identification of the settler's town as "strongly-built" and "well-fed", whose streets are "clean", whereas Paradise could be illustrative of his conception of "the native town" as "a place of ill fame" (Fanon 1963: 39). As Darling describes:

Budapest is big, big houses with satellite dishes on the roofs and neat graveled yards on trimmed lawns, and the tall fences and Durawalls and the flowers and the big trees heavy with fruit that's waiting for us since nobody around here seems to know what to do with it. It's fruit that gives us courage, otherwise we wouldn't dare be here. I keep expecting the clean streets to spit and tell us to go back where we came from. (Bulawayo 2013: 4)

The fact that the sole reason why the children move around Budapest is their hunger appears in connection with their discernible fearfulness in the area. It seems a paradox, however, that this emotion is represented as experienced by those subjects who are supposed to be the feared ones in this location, in particular owing to the reference to the presence of forms of protection such as fences and concrete walls. Apart from this, the use of the popular expression "go back to where you came from" deserves a special focus as it significantly conjures up the image of the immigrant who is rejected in a new country of residence. This refers to the children, who are in a place whose name refers precisely to an altogether different country. However, as Darling suggests by saying that the inhabitants of Budapest appear not to know what to do with the fruit in their gardens, the figure of the stranger could be identified both with them and with the native population. To be more precise, while the condition of strangeness of the white population appears to be based on their unfamiliarity with the environment, in the case of the children it seems to be strongly associated with their threatening condition as the abject poor of the area.

The contrast between Paradise and Budapest, besides becoming evident through a distinct depiction of a sharper racial and socioeconomic difference than in the 
initial lines of Americanah, seems to be above all articulated through "the language and imaginary of disgust" which still characterises racist discourses (Miller 2004: 154). This is manifest through the opposition between cleanliness and dirt that the repeated references to the eschatological establish in this narrative, especially through the repetition of the word "kaka" in allusion to Paradise, as when Darling states that, in comparison with her town, "Budapest is not a kaka toilet for anybody to just walk in" (Bulawayo 2013: 12). The disgust discourse in the narration, as in the case of Adichie's narrative, can thus be read as representing a clear case of sociospatial exclusion - for after all, it designates those spaces in which the racialised "other" is depicted as alienated.

Bearing in mind Kristeva's identification of abjection with all that is simultaneously loathsome and captivating about our bodies and bodily experiences, such as pregnancy, death, illness, vomiting, defecation, sex or fluids, the explicit reference to the abject in Bulawayo's novel is in addition complemented with the sordid depiction of an eleven-year-old girl who becomes pregnant after being raped by her grandfather (2013: 40). Disgust is mostly stimulated in the reader when Darling refers to her process of urinating in a cup, whose content Chipo swallows in preparation for the rudimentary abortion her friends want to perform on her using a clothes hanger (81). In the same vein, the depiction of Darling's father's return to Paradise includes the hyperbolic reference to human body waste, illustrating the consequences of the man's suffering from AIDS. Considering Paul Rozin and April E. Fallon's clarification that "vomiting involves expelling something that has already been digested, and hence incorporated into the body of the one who feels disgust" (in Ahmed 2014: 94), it is in particular worth focusing on the continuous reference to his unstoppable throwing up so as to deepen the recognition of the significance of this quotation:

Father comes home after many years of forgetting us, of not sending us money, of not loving us, not visiting us, not anything us, and parks in the shack, unable to move, unable to talk properly, unable to anything, vomiting and vomiting, Jesus, just vomiting and defecating on himself, and it smelling like something dead in there, dead and rotting, his body a black, terrible stick [...]. (Bulawayo 2013: 89)

Far from a simple description of the health condition of the man, these lines seem above all to constitute a sharp criticism of the failed process of decolonisation which, as illustrated through the protagonist's displacement to the United States, still obliges Zimbabweans to "leave in droves" to other countries (Bulawayo 2013: 145). Indeed, Darling's father contracts AIDS after moving to South Africa to find work. Accordingly, the reference to the vomiting could be read as revulsion towards a scheme characterised by corruption, disease, conflict and a slow economy the Zimbabwean population in the novel no longer wants to belong to. 


\section{Ángela Suárez Rodríguez}

The rejection felt by native Zimbabweans towards their own land is depicted in the novel through the explicit illustration of the children's dreams about leaving for what, in their words, are "country-countries", when the narrator explains the basics of one of their games:

But first we have to fight over the names because everybody wants to be certain countries, like everybody wants to be the U.S.A. and Britain and Canada and Australia and Switzerland and France and Greece and them. These are the countrycountries. If you lose the fight, then you just have to settle for countries like Dubai and South Africa and Botswana and Tanzania and them. They are not countrycountries, but at least life is better than here. Nobody wants to be rags of countries like Congo, like Somalia, like Iraq, like Sudan, like Haiti, like Sri Lanka, and not even this one we live in - who wants to be a terrible place of hunger and things falling apart? (Bulawayo 2013: 49)

Besides the contrast between the neoimperialist centres and their margins in the current international scene, therefore broadening the scope of earlier spatial oppositions in the narrative, this quotation raises another issue which is central for a consideration of the spatialising role of disgust in the social sphere. The desire to be identified with current hegemonic countries, and the consequent contempt for one's own condition, can be interpreted through Tyler's notion of "social abjection" as a social force which might lead to the perception of oneself as the abject (Tyler 2013: 21). It is not just that the children seem to idolise Budapest in their perception of the area as of a clear higher status than Paradise, but Darling and her friends appear also to be aware of their own positionality as the national waste, notably in their encounter with the NGO people the children "are careful not to touch" (Bulawayo 2013: 54). The narrator clarifies that, "even though they are giving [them] things", it is evident that these people "do not want to touch [them] or for [them] to touch them" (54) - a behaviour which can be better understood through Ahmed's primal assumption that disgust "is dependent upon $[\ldots]$ the proximity between the surfaces of bodies" and so involves a "double movement" which is "crucial to the intercorporeality of the disgust encounter" (2014: 85). Indeed, the NGO people move towards the children, only then to pull away from them.

The same recognition of oneself as the abject can be perceived in the episode when the children, who are stealing guavas in a private garden in Budapest (Bulawayo 2013: 120), enter a house the Zimbabwean revolutionaries have shattered. Specifically, this can be seen in the scene when the gang find themselves seeing the reflection of their faces in a bathroom mirror on which the words "Black Power" had been written using feces (130). Following Ahmed's reflections, the sticky sign the words represent and the sticky object the children embody "cannot be separated through any simple distinction between literal and metaphorical", for 
"stickiness involves a form of relationality [...] in which the [concerned] elements [...] get bound together" (Ahmed 2014: 91). For the same reason, neither is it complicated for the reader to compare the children to the revolutionaries who have produced that sign on the mirror and are, thus, in this chain of production and identification with the abject. In fact, apart from their equally inappropriate experience in the house without its owners' consent, there seems to be a further correlation between the act of the revolutionaries in the toilet and the children's earlier threats to spread their dirt around Budapest. Godknows is especially explicit in these terms through his statement "You want us to come at night and defecate all over? Or steal things?" (Bulawayo 2013: 47), addressing one of the Chinese men who are building a shopping centre on the outskirts of Budapest. The connection could even be established between the desire of the revolutionaries to restore a black Africa, as their words “Africa for Africans!" reveal (111), and the children's claim for their place when, in Darling's words: “Going back to Paradise, we do not run. We just walk nicely like Budapest is now our country too, like we built it even, eating guavas along the way and spitting the peels all over to make the place dirty" (11). The description of their attitude as confident pedestrians moving around Budapest is reminiscent of de Certeau's reflection on walking as an everyday practice of spatial appropriation, in particular through their willful act of contaminating the place by spitting. It seems to be, however, the physical embodiment inherent to this action which reveals the children as abject subjects of the space inhabited.

The power of disgust discourse to create abject subjects and objects, and not simply to define them, is also illustrated in Adichie's narrative when Morgan, the oldest daughter of Ifemelu's first boss in the United States, refers to her uncle's relationship with Ifemelu as "disgusting". Her attitude of contempt is in addition emphasised in the same terms through the narrator's comment that the girl is "looking genuinely disgusted" when she states her opinion (Adichie 2014: 194), which demonstrates that the problem of blood mixing still "recurs and attracts disgust in discourses of both race and class" (Miller 2004: 156). However, the importance of the episode under discussion relies above all on its representation of Ahmed's fundamental consideration that " $[\mathrm{t}]$ o name something as disgusting $[\ldots]$ in the speech act [...] 'That's disgusting!' is performative", meaning that "[i]t relies on previous norms and conventions of speech, and it generates the object that it names" (2014: 93). In this sense, the consideration of Ifemelu's relationship with her new American partner as "disgusting" through this same statement positions Ifemelu as the disgust object. It is, nevertheless, the relevance of not "neutralis[ing] the differences between objects", as well as of realising "that some objects become stickier than others given past histories of" association (Ahmed 2014: 92), which explains the reason why Ifemelu's boyfriend is not regarded in 


\section{Ángela Suárez Rodríguez}

the same terms although he is also one of the "disgusting" partners. Nonetheless, as Ahmed further clarifies, the speech act mentioned above does not only create subjects and objects of disgust as a result of the stickiness of this emotional notion, but it also involves a process of casting off or, in other words, an abjection of those "whose proximity is felt to be threatening and contaminating" (2014: 94) - that is, the racialised "other" from which a distance is created in the hegemonic urban space.

Ifemelu's adoption of a social condition of abjection in the United States seems to be in fact the result of a social mechanism of an "inclusive exclusion" which benefits from the vulnerability of the racialised 'other' to perpetuate hegemonic racial relations. Depicted in the form of a symbolic marginality given by the consideration of the subject as an essential but unrecognised part of the nation, this positionality is represented in both narratives through the depiction of the different jobs their characters either vie for or eventually perform in their status as undocumented immigrants. Specifically, it is the description of their working conditions and workplaces which stimulates an emotion of disgust and illustrates a clear state of social abjection in their narrations. In the case of We Need New Names, this is manifest when Darling outlines that her work routine consists of cleaning toilets, bagging groceries and sorting out bottles and cans (Bulawayo 2013: 251). Particularly explicit is her description of a grocery store:

The beer bottles are the worst. They will come with all sorts of nasty things. Bloodstains. Pieces of trash. Cigarette stubs drowning in stale beer the color of urine, and one time, a used condom. When I started working here, back in tenth grade, I used to vomit on every shift. (253)

In the same vein, the depiction of the workplace of the undocumented immigrant in Americanah stimulates disgust in an explicit manner through the graphic description of the apartment in South Philadelphia where Ifemelu goes for an interview:

At first, Ifemelu forgot she was someone else. In an apartment in South Philadelphia, a tired-faced woman opened the door and led her into a strong stench of urine. The living room was dark, unaired, and she imagined the whole building steeped in months, even years, of accumulated urine, and herself working every day in this urine cloud. From inside the apartment, a man was groaning, deep and eerie sounds; they were the groans of a person for whom groaning was the only choice left, and they frightened her. (Adichie 2014: 130)

The hyperbolic illustration of the abject in the form of body fluids represents an obvious allusion to disgust. Moreover, Ifemelu's later interview "in a cramped home office", which "smelled slightly of damp" and was situated "in the basement of a strange house" in Philadelphia is consistent with this disgust discourse in the 
narration (Adichie 2014: 143). Interestingly, Ahmed's perception of the intersection between disgust and the abject through the identification of "that which is below" constitutes a useful prism through which to interpret this episode. In particular, her observation of the connection of this lowness with "other bodies and other spaces" which are below the hegemonic entities in power relations, as well as with the lower corporeal regions associated both with body waste and sexuality (2014: 89), appear to be the most enlightening on this occasion.

The correlation can be, thus, first established between Ifemelu's condition as a black illegal worker —which places her in a position of "belowness" in the hierarchical power structure in the United States - and her identification of "low bodies" in power relations. Second, the fact that the interview is conducted in the part of a building that is below ground level - together with the damp smell of the place stimulating a sense of disgust - seems again to allude to this particular positionality to which her social situation leads. Ahmed's third association with lower corporeal regions is prompted by the fact that the services this man requests from her are comparable to prostitution. This is implicit when he clarifies that he is looking for someone who helps him to "relax", but quite explicit when, in answer to her request for greater precision, he tells her that she "can give [him] a massage" (Adichie 2014: 144).

In a desperate attempt to improve her living condition as a black immigrant woman in the United States, Ifemelu ends up carrying out the services requested by the tennis coach. The narrator describes how, "even after she had washed her hands" after their sexual encounter, "holding the crisp, slender hundred-dollar bill he had given her, her fingers still felt sticky", as if "they no longer belonged to her" (Adichie 2014: 154). Indeed, Ahmed's consideration that the association of emotions with objects or other bodies is dependent on contact and based on a relation of "stickiness" serves once more to illustrate Ifemelu's emotional state (2014: 18). In the same way that Ahmed understands that "emotions can move through the movement or circulation of objects" due to the emotional stickiness of these objects (2014: 11), Ifemelu's feeling of disgust towards the fluids in her fingers appears to translate into a sense of self-disgust when the narration switches from one location to another and places the protagonist back in her flat. In particular, this becomes evident through the resemblance between her reaction towards her clothes and her attitude towards her own self in the following lines:

Back in her apartment, she washed her hands with water so hot that it scalded her fingers, and a small soft welt flowered on her thumb. She took of all her clothes and squashed them into a rumpled ball that she threw at a corner, staring at it for a while. She would never again wear those clothes, never even touch them. She sat naked on her bed and looked at her life, in this tiny room with the mouldy carpet, the hundreddollar bill on the table, her body rising with loathing. She should never have gone 


\section{Ángela Suárez Rodríguez}

there. She should have walked away. She wanted to shower, to scrub herself, but she could not bear the thought of touching her own body, and so she put on her nightdress, gingerly, to touch as little of herself as possible. (Adichie 2014: 154)

Besides the presence of a "mouldy carpet", Ifemelu's reaction towards her own corporeality accentuates the atmosphere of disgust in her room through the illustration of her desire to create distance from that which is regarded as revolting. The imaged contact with what had made her fingers become sticky leads her to the compulsive washing and emphasised desire to bathe that Christal Badour and Thomas Adams have identified as a response to a traumatic sexual experience such as Ifemelu's (2015: 130). For them, this response can be manifested as either "intended to remove contaminants from the skin" (2015: 135), as when the protagonist is still in his apartment and her fingers are depicted as "sticky" (Adichie 2014: 154), or "to escape unwanted negative emotions" (Badour and Adams 2015: 135), as the description of her state once in her flat illustrates (Adichie 2014: 154). Nevertheless, far from a mere avoidance of either dirt or a temporary undesired emotion, Ifemelu's behaviour could be read as her struggle to escape the abject condition that her acts may have adhered to her person. In line with Ahmed's reflections on "the complexity of the relationship between the [colonial] past and [the imperialism of the] present" (2000: 11), it should not be forgotten, however, that her racialised, gendered and sexualised abjectionality as a black immigrant woman in the hegemonic metropolis is primarily the result of strongly interiorised histories of association.

\section{Conclusion}

The identification of Ifemelu, in Chimamanda Ngozi Adichie's Americanah, and Darling, in NoViolet Bulawayo's We Need New Names as characters who are involved both physically and emotionally with the urban spaces depicted in their narrations confirms the current trend of black diasporic writers to replace the modern flânerie with Isabel Carrera Suárez's “postcolonial, post-diasporic pedestrian" (2015: 854). Furthermore, the recognition of their embodied urban experience has enabled the understanding of the geographies of disgust in these two iconic Afrodiasporic narratives as illustrative of the racialisation processes which condition their subjectivation as Afrodiasporians in contemporary postcolonial cities.

Even though disgust-invoking images proliferate in both novels, their meaning changes in the episodes set in non-western urban spaces and in those dealing with their protagonists' experiences living in diaspora. While disgust is more closely associated with the diverse forms of violence and decay resulting from a failed 
process of decolonisation through the depiction of a racially fragmented nonwestern urban space in the first case, this emotion is mostly related to an ambivalent social status in those situations in the hegemonic metropolis. Specifically, the identification of a disgust discourse in the representation of western urban spaces enables the emergence of a symbolic marginality which defines the liminal condition of migrant abjectionality in this neoimperial urban space. The importance of this social abjection that current disgust discourses impose upon postcolonial migrants such as Ifemelu and Darling relies on its representation of an ambivalent positionality which is based on an inclusive exclusion, hence revealing itself as a critical conditioning factor in their process of subjectivation.

In conclusion, the representation of urban spaces in both Chimamanda Ngozi Adichie's Americanah and NoViolet Bulawayo's We Need New Names has been demonstrated to have significance beyond their mere physical description. Providing a critical look at the racially spatialised global cities of the present, these have also been identified as contributing to the representation of the socioemotional experiences of their protagonists. Through a specific focus on the disgust discourse embedded in their narrations, emotions have in turn been confirmed central for an accurate interpretation of the spaces in which the action in these narratives occurs. Ultimately, it has been shown that the examination of spatio-emotional textualities in the form of geographies of disgust constitute a suitable basis through which to understand the social condition of abjection and its representation in contemporary Afrodiasporic fiction. ${ }^{1}$

\section{Notes}

1. The author wishes to acknowledge that the research carried out for the writing of this article has been funded by the Spanish Ministry of Science, Innovation and Universities within the $R \& D$ project "Strangers and Cosmopolitans: Alternative
Worlds in Contemporary Literatures", STRANGER (RTI2018-097186-B-I00), as well as the support of the Government of Asturias for the Research Group "Intersections: Contemporary Literatures, Cultures and Theories" (IDI/ 2018/ 000167).

\section{Works Cited}

Adichie, Chimamanda Ngozi. (2013) 2014. Americanah. London: Fourth Estate. 


\section{Ángela Suárez Rodríguez}

Sara. Strange Encounters: Embodied Others in Post-Coloniality. London and New York: Routledge: 1-17.

Ahmed, Sara. (2004) 2014. The Cultural Politics of Emotion. Edinburgh: Edinburgh U.P.

Anderson, Ben. 2017. "Affect". In Jayne, Mark and Kevin Ward (eds.) Urban Theory: New Critical Perspectives. Oxon and New York: Routledge: 19-29.

Badour, Christal L. and Thomas G. AdAms. 2015. "Contaminated by Trauma: Understanding Links between Self-disgust, Mental Contamination, and Posttraumatic Stress Disorder". In Powell, Philip A., Paul G. Overton and Jane Simpson (eds.) The Revolting Self: Perspectives on the Psychological, Social, and Clinical Implications of Self-Directed Disgust. London: Karnac. 127-150.

BRIDGE, Gary and Sophie Watson. 2011. "Reflections on Affect". In Bridge, Gary and Sophie Watson (eds.) The New Blackwell Companion to the City. Chichester: WileyBlackwell: 277-287.

Bulawayo, NoViolet. 2013. We Need New Names. London: Chatto and Windus.

CAPron, Guénola. 2014. “Cuerpos, espacios y emociones: aproximaciones desde las ciencias sociales". Polis 10 (1): 159-165.

Carrera SuÁrez, Isabel. 2015. "The Stranger Flâneuse and the Aesthetics of Pedestrianism". Interventions 17 (6): 853-865.

FANON, Frantz. (1961) 1963. "Concerning Violence". In Fanon, Frantz. The Wretched of the Earth. Trans. C. Farrington. New York: Grove Press: 35-106.

HaYter, Teresa. (2000) 2004. "Re-Open the Borders". In Hayter, Teresa. Open Borders: The Case Against Immigration Controls. London: Pluto Press: 149-172.

Herbert, Caroline. 2014. "Postcolonial Cities". In McNamara, Kevin R. (ed.) The Cambridge
Companion to the City in Literature. Cambridge: Cambridge U.P.: 200-215.

Hostetter, Ellen. 2010. "The Emotions of Racialization: Examining the Intersection of Emotion, Race, and Landscape through Public Housing in the United States". GeoJournal 75 (3): 283-298.

Kristeva, Julia. 1982. Powers of Horror: An Essay on Abjection. New York: Columbia U.P.

Lindón, Alicia. 2007. "La ciudad y la vida urbana a través de los imaginarios urbanos". Eure 33 (99): 7-16.

LUPTON, Deborah. 1998. The Emotional Self: $A$ Sociocultural Exploration. London, Thousand Oaks and New Delhi: Sage.

Madanipour, Ali. (1996) 2016. "Social Exclusion and Space". In Legates, Richard T. and Frederic Stout (eds.) The City Reader. London and New York: Routledge: 201-211.

Menéndez Tarrazo, Alicia. 2010. Teoría urbana postcolonial y de género: la ciudad global y su representación. Oviedo: KRK.

Miller, Susan B. 2004. “Group Identities and Hostility across Borders: Affairs of Ethnicities, Classes, and Sects". In Miller, Susan B. Disgust: The Gatekeeper Emotion. London: Analytic Press: 153-169.

SIBLEY, David. 1995. "Geographies of Exclusion". In Sibley, David. Geographies of Exclusion: Society and Difference in the West. London and New York: Routledge: 1-117.

SimOnSEN, Kirsten. 2008. "Practice, Narrative and the 'Multicultural City': A Copenhagen Case". European Urban and Regional Studies 15 (2): 145-158.

Thrift, Niger. 2004. "Intensities of Feeling: Towards a Spatial Politics of Affect". Geografiska Annaler: Series B, Human Geography 86 (1): 57-78.

TYLER, Imogen. 2013. Revolting Subjects: Social Abjection and Resistance in Neoliberal Britain. London and New York: Zed Books. 